\title{
POST-PRINT
}

Bonsignori, V. (2018) "Using films and TV series for ESP teaching: A multimodal perspective", in B. Crawford Camiciottoli and M.C. Campoy Cubillo (eds) Multimodal Perspectives on English Language Teaching in Higher Education, Special Issue of System, 7 (2018): 58-69 (ISSN 0346-251X) https://doi.org/10.1016/j.system.2018.01.005

\section{Using films and TV series for ESP teaching: A multimodal perspective ${ }^{1}$}

\author{
Veronica Bonsignori
}

Department of Philology, Literature and Linguistics, University of Pisa, Italy

P.zza Torricelli 2, 56126, Pisa, Italy

veronica.bonsignori@unipi.it, +39 0502215080

\begin{abstract}
This paper presents the results of a project carried out at the Language Centre of the University of Pisa in partnership with the Language Center of the University of California at Berkeley to collaborate in the development of the Library of Foreign Language Film Clips (LFLFC), which aims to promote the learning of language and culture through films. A selection of clips cut from films and TV series was purposefully chosen as they pertain to different genres and are characterised by the use of English in specialised domains (i.e., law, politics, economics, tourism, and medicine). They are used to show how various semiotic resources work together to construct meaning in ESP and how they can provide useful tools for research and teaching in ESP contexts. In language teaching, a multimodal approach can help students learn to exploit modes beyond verbal language (e.g., visual, gestural, and spatial) to both understand and produce texts in the target language more effectively. This becomes particularly important in situated communicative contexts where domain-specific discursive, pragmatic, and cultural features can create significant obstacles for language learners.
\end{abstract}

\section{Keywords}

ESP; film; language teaching; TV series; multimodal corpus; multimodality 


\section{Introduction}

The present study aims to illustrate the results of a project carried out at the Language Centre of the University of Pisa for the collection of a multimodal corpus of clips cut from films and TV series representing five specialised domains, i.e., law, politics, economics, medicine and tourism. The corpus was inspired by the Library of Foreign Language Film Clips (LFLFC) ${ }^{2}$ developed at the University of California at Berkeley, with whose partnership the project was carried out. The main aim of the project was to promote the learning of language and culture through films and, especially, to create useful material for ESP contexts. In effect, the use of audiovisual products, where different semiotic codes contribute to the construction of meaning, has proved to be a valuable tool in language teaching, especially within the multimodal analysis framework (Jewitt 2014). This can help students learn to exploit modes beyond verbal language (e.g., visual, gestural, and spatial) to both understand and produce texts in the target language more effectively (O’Halloran et al. 2016). This becomes particularly important in situated communicative contexts where domain-specific discursive, pragmatic, and cultural features can create significant obstacles for language learners.

\section{Literature Review}

Communication is intrinsically multimodal, since various semiotic resources are intertwined and all contribute to the meaning-making process in a given situational context, so that both verbal and non-verbal cues are crucial in order to interpret a message fully. Since the pioneering and seminal work by Kress and van Leeuwen (1996) and Lemke (1998), there has been extensive research on multimodality, which has become a significant issue (cf. Norris 2004, Scollon and Levine 2004, O’Halloran 2011, Jewitt 2014), especially nowadays in relation to the features of the new communication media. Indeed, as pointed out by Kress (2003: 1), there has been "on the one hand, the broad move from the now centuries long dominance of writing to the new dominance of the image and, on the other hand, the move 
from the dominance of the medium of the book to the dominance of the medium of the screen". In this way, visual and aural elements also play an important role in the representation of reality. This has had a strong impact on educational techniques, so much so that the concept of "multiliteracies" was introduced in 1996 by the New London Group, formulating a pedagogic agenda in response to the changes in the communicative and representational landscape. According to Kalantzsis and Cope (2013: 3963):

we need to extend the range of literary pedagogy so that it does not exclusively privilege alphabetical representations. In today's learning environments, we need to supplement traditional reading and writing with these multimodal representations, and particularly those typical of the new, digital media.

The advantages of using audiovisual products in language teaching have been acknowledged in several studies. These show how exposure to visual and aural elements in films helps learners to widen vocabulary (cf. Sherman 2003, Webb and Rodgers 2009, Kaiser 2011), to learn certain pragmatic strategies in conversation, e.g., routines (cf. Lin 2014, in Internet TV; Bruti 2015, in films), and to develop oral skills in general (Dikilitas and Duvenci 2009). But, more importantly, it also gives students the chance to "see the "language in use" (Harmer 2007: 308). This allows them to see how paralinguistic elements are used in different contexts and cultures, thus also broadening their intercultural communication competence, and to listen to various accents. In addition, it helps them become more aware of non-verbal cues (e.g., gestures, facial expression, gaze direction, physical proximity, as well as the use of pauses and intonation patterns) and of how they contribute to integrating or supporting the verbal message. Indeed, in teaching contexts, film has been described as "an authentic source material (that is, created for native speakers and not learners of the language)" (Kaiser 2011: 233, Sherman 2003). Even though some scholars defined it as "written-to-be-spoken-as-if 
not-written" (Gregory and Carroll 1978), and “oralidad prefabricada" [Eng. prefabricated orality] (Chaume 2004: 168), several recent studies have demonstrated the similarities between film language and spontaneous face-to-face conversation, in terms of authenticity and spontaneity (Kozloff 2000, Forchini 2012, Bonsignori 2013). The same holds for TV dialogue (cf. Quaglio 2009), which is a subtype of "scripted/constructed dialogue" written to sound natural and believable (Bednarek 2010: 63). It features specific narrative and semiotic elements that are not totally remote from those characterising films, but which are limited by broadcasting time and modality. Moreover, it is not always easy to find available material retrieved from spontaneous conversation in specialised contexts to be used in the ESP class. Even textbooks may not be enough, as in the case of medical communication textbooks compared to which spoken language shows a great amount of deviation (Nagy 2010). This is why relying on films, the quintessence of multimodal products (Bateman 2013), or TV series to teach English in specialised settings can be an effective solution. In other domains, such as law, the language of films and TV shows has proved to share several features with real communication in legal contexts, as shown in the very recent study carried out by Forchini (2017), thus confirming that both genres are suitable for the teaching of legal English (cf. Csomay and Petrović 2012, Vyushkina 2016).

\section{Material and Methods}

The advantages of using multimodal corpora have been extensively described in the literature (cf. Ackerley and Coccetta 2007, Querol-Julián 2010, Knight 2011). Unlike monomodal corpora, generally limited to written texts, they allow users to analyse several aspects of oral communication, since they provide audiovisual material. However, multimodal corpora are much more limited in size. This is mainly due to the fact that the compilation process is much more complex, as the addition of aural and visual information means that "aligning and transcribing (if at all) different streams of data is naturally more time consuming and 
technically difficult than when dealing with a single stream” (Knight 2011: 397). Moreover, their scope is often limited, because multimodal corpora, as well as ESP corpora, tend to be domain specific (Knight 2011). Therefore, another crucial issue is that of representativeness. However, as Rizzo (2010: 5) points out, "[i]n spite of the efforts made, the representativeness of a corpus will only be approximate, since it is not possible that a limited compilation of texts fully represents the whole language of a discourse community".

The multimodal corpus utilized for this study was inspired by the BLC Library of Foreign Language Film Clips (LFLFC) developed at the University of California at Berkeley (Kaiser 2011), with which the Language Centre of the University of Pisa established a partnership aimed at developing this database. Some films and TV series were selected based on the discourse domain they represent, namely Political Science, Business \& Economics, Law, Health \& Medicine, and Tourism. They were carefully watched and 94 clips were cut (Table 1), choosing sequences where specialised discourse is at play and where different genres are portrayed (cf. sections 4.1, 4.2 and 4.3 for details).

\begin{tabular}{|c|c|c|c|}
\hline DOMAIN & TITLE & GENRE & CLIPS \\
\hline \multirow[t]{2}{*}{ Political Science } & The Ides of March (2011, G. Clooney) & Film & 10 \\
\hline & The Iron Lady (2011, P. Lloyd) & Film & 9 \\
\hline Business \& Economics & Margin Call (2011, J.C. Chandor) & Film & 7 \\
\hline \multirow[t]{3}{*}{ Law } & The Good Wife (2009, Season 1, ep. 1) & \multirow[t]{3}{*}{ TV series } & 6 \\
\hline & The Good Wife (2009, Season 1, ep. 2) & & 6 \\
\hline & The Good Wife (2009, Season 1, ep. 3) & & 10 \\
\hline \multirow[t]{2}{*}{ Health \& Medicine ${ }^{3}$} & Code Black (2015, Season 1, ep. 1) & \multirow[t]{2}{*}{ TV series } & 10 \\
\hline & Code Black (2015, Season 1, ep. 2) & & 12 \\
\hline Tourism & Letters to Juliet (2010, G. Winick) & Film & 10 \\
\hline
\end{tabular}




\begin{tabular}{|l|l|l|}
\hline To Rome with Love (2012, W. Allen) & Film & 4 \\
\hline Under the Tuscan Sun (2003, A. Wells) & Film & 11 \\
\hline
\end{tabular}

Table 1. The multimodal corpus of film and TV series clips relevant in ESP contexts.

Every clip lasts a maximum of 4 minutes. Speech was transcribed and annotated with searchable descriptors of linguistic, pragmatic, and cultural features. Moreover, the clips were analysed multimodally using the annotation software ELAN (Wittenburg et al. 2006) ${ }^{4}$, which allows users to investigate how verbal and non-verbal elements interact to generate meaning. The analytic framework created in the ELAN software is multi-levelled and consists of a series of tiers (cf. Fig. 1 as an example, where tiers are listed on the left): 1) Transcription, 2) Gesture_description, where all the gestures used by the speaker are annotated using labels based on Querol-Julián's (2011) model (e.g., 'Pu', standing for 'palm up'), 3) Gesture_function, following Kendon (2004) and Weinberg et al. (2013)'s classifications of gesture functions (i.e., modal, performative, parsing, and indexical, representational, social, respectively), 4) Gaze (e.g., up, down, etc.), 5) Face (e.g., frowning, smiling, etc.), 6) Head (e.g., 'QN' for 'quick nod'), 7) Prosody (i.e., indicating the occurrence of prosodic stress on certain words) and, finally, 8) Notes, where annotations regarding camera angles or the audience's behaviour are inserted, since these are important elements to consider when analysing films or TV series (Bonsignori 2016), e.g., sometimes the camera focuses on the audience or the interlocutor while the speaker is giving his/her speech, so that gestures or head movements cannot be taken into account.

These multimodal corpus sequences provide the opportunity to examine and interpret modes that are not present in current ESP textbooks, which makes the present multimodal corpus a valuable and useful tool for educational purposes.

\section{Analysis}


In the following sections, three clips representing the domains of Political Science, Law and Tourism will be analysed from a multimodal perspective, highlighting key verbal and nonverbal features that are relevant in each specialised domain. Each analysis will be followed by specific classroom applications, in order to shed light on how to take advantage of audiovisual products in ESP contexts.

\subsection{Political Science}

Two films were chosen to represent the domain of political science, namely The Ides of March (2011, George Clooney) and The Iron Lady (2011, Phyllida Lloyd) (cf. Bonsignori 2016); however, only the latter will be analysed in this section. The Iron Lady (2011, Phyllida Lloyd) is a biopic on Margaret Thatcher (Meryl Streep) and on how she succeeded in being elected as the first female British Prime Minister. The clips selected from these two films i.e., 10 from the first film and 9 from the latter - generally consist of scenes portraying different political contexts and genres such as political interviews, various types of political speeches (e.g., the endorsement speech, a speech during a political debate) with different kinds of audience (e.g., other politicians in the House of Commons, supporters), conversations between campaign staffers and reporters, etc. Indeed, these clips provide the opportunity of studying and learning specialised vocabulary, that is, certain political terms and phrases, but especially some rhetorical strategies that are a key feature of political discourse for persuasion (Partington and Taylor 2010), i.e., metaphors, similes, antithesis, parallel structures, etc. Most importantly, these very often co-occur with non-verbal cues such as gestures, gaze direction, head movements, as well as prosodic stress and the use of pauses. In effect, the relevance of bodily behaviour in political communication and persuasive discourse has been widely acknowledged by several scholars (cf. Atkinson 1984; Streeck 2008; Poggi et al. 2013, among many). This is why when analysing and teaching 
political discourse, it is important to take into account the interplay between verbal and nonverbal elements in the meaning-making process.

Clip 1 was cut from The Iron Lady, is approximately one minute long (00:01:09') and set in the House of Commons in the British Parliament, where Prime Minister Margaret Thatcher makes a speech for the Falklands victory in 1982. In the opening sequence, we can see images of the celebrations in Britain, accompanied by music played by a triumphant marching band, while her voice can be heard off-screen, uttering the first sentence of her speech (within square brackets), which is transcribed fully below. When the camera is back in the House of Commons Chamber, the Prime Minister is standing at the Dispatch Box, surrounded by members of the Conservative and Labour parties.

[We congratulate the men and women of our armed forces for their skill, bravery, and loyalty to this country]. We were faced with an act of unprovoked aggression, and we responded, as we have responded in times past: with unity, strength, and courage!

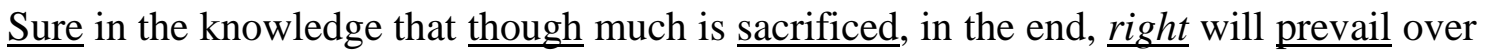
wrong. And I put it to the Right Honourable Gentleman opposite that this is not a day

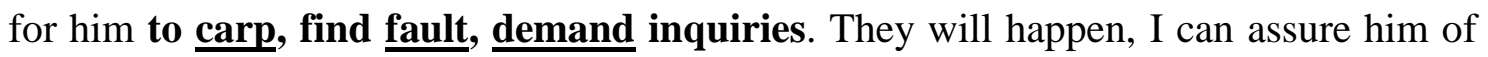
$\underline{\text { that, }}$ for we have nothing to hide. №. This is a day to put differences aside, to hold one's head high and take pride in being British!

This is an example of a planned speech, since despite its considerable brevity, it is characterised by a succession of rhetorical strategies, namely four parallel structures, in this case tricolons, and two contrasts. The tricolons consist of three elements, the last of which is generally longer than the preceding two, in order to add emphasis to the whole message, and are highlighted in bold in the transcript; while the two contrasts, by antonymy (right/wrong) and antithesis (This is not a day/This is a day), are in italics. The key elements in the speech 
are also underlined to indicate that they bear a prosodic stress, which in fact is used to utter the three elements in all the parallel structures. As a very recent study on the multimodal analysis of political discourse in films (Bonsignori 2016) has shown, very few gestures are used in this clip, i.e., only two, since head movements are preferred instead, which often consist of quick nods to mark different units in the utterance and to put emphasis on certain terms. However, one of the two gestures used by Margaret Thatcher here is at the beginning of the last tricolon, on the first element, when she uses the hand gesture described as 'open hand moving forward to the right' (i.e., 'OHMfr' in the Gesture_description tier in Fig. 1) while uttering the word aside, which also bears a prosodic stress (see the Prosody tier). This is an iconic gesture that helps to understand what is being said, thus performing a representational function (Weinberg et al. 2013) (as indicated in the Gesture_function tier).

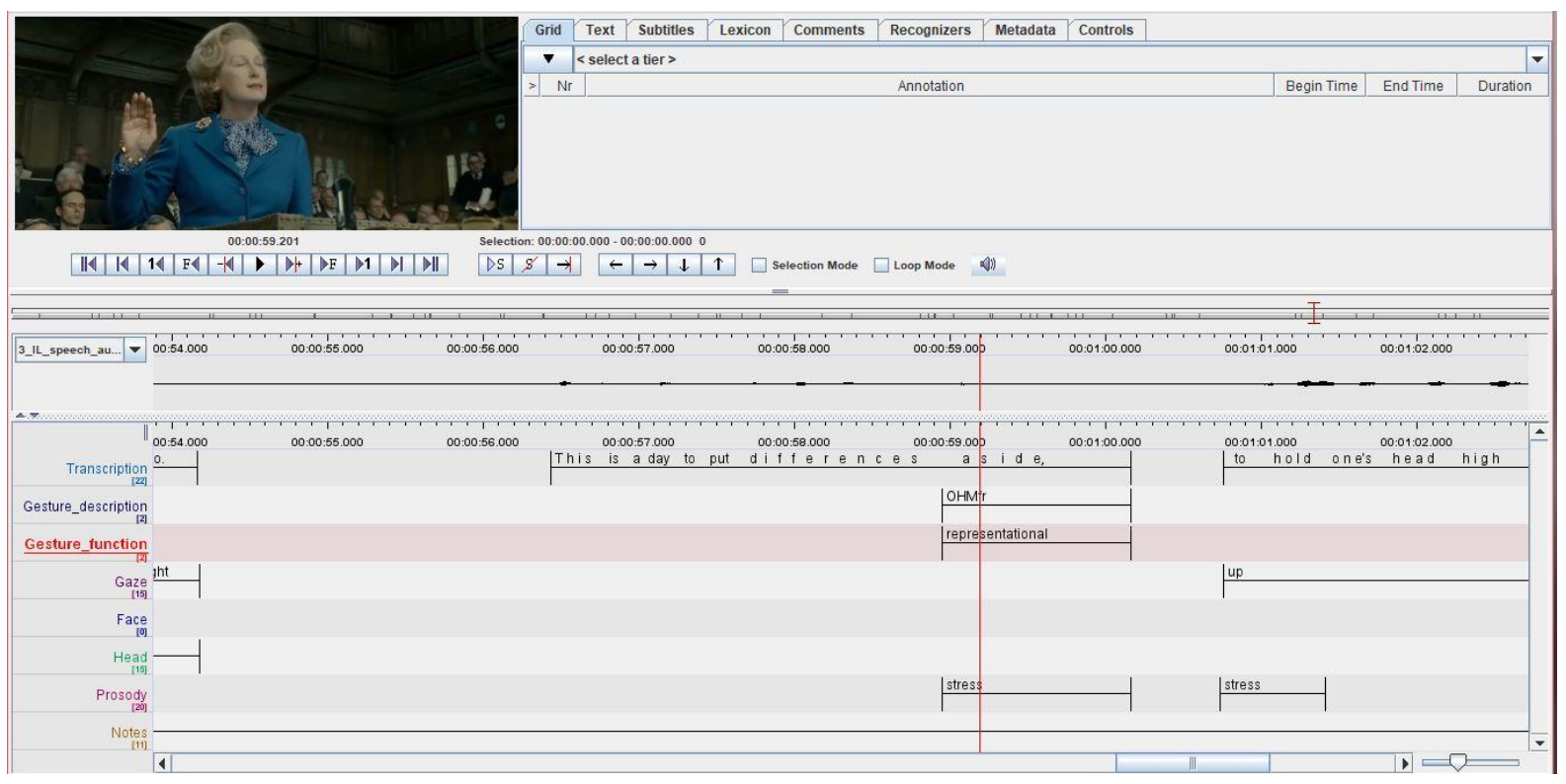

Fig. 1 - Multimodal analysis of a tricolon in the political speech (Clip 1)

Before using Clip 1 in the Political Science class, political speech as a genre should be introduced first by pointing out its main features, i.e., monologic, planned, and usually written for politicians by dedicated speech writers (Beard 2000). Then, the film extract 
should be properly described to students, as to setting, participants, etc., in order to carry on with the various activities. The students should watch it twice, the second time with English subtitles or following the scene reading the transcript, in order to help them to understand what is being said. Clip 1 is not very long and, apart from the very beginning, where Margaret Thatcher's voice overlaps with other sounds, such as music and people's voices, she speaks clearly and at a low pace that is quite easy to follow. Students should then watch or better, listen to - the clip a third time, but concentrating on the aural cues, and be asked to identify verbal elements with a prosodic stress. Finally, non-verbal elements such as gestures and head movements should be analysed by watching the clip one last time, and indicating when these are employed by the speaker and why. This should lead to the next content topic of the lesson, namely the rhetoric strategies used in political speeches for persuasion, i.e., in this case, tricolons, antonymy and antithesis. Finally, a discussion on the integration between the different semiotic codes and how they all contribute to generating meaning in this context should be carried out, so that students become aware of the tools used by politicians to persuade their interlocutors.

\subsection{Law}

For the legal domain the popular American TV series The Good Wife (2009-2016) was chosen as an example of the American legal system. It tells the story of Alicia Florrick, wife of a former state's attorney, Peter Florrick (now in jail for corruption and a sex scandal), who has to go back to work as a litigator in order to provide for her family.

From the first three episodes of the first season, 12 clips were selected (cf. Table 1 for details), mostly showing various legal contexts and genres such as meetings at the firm, discussions of a case, pre-trial hearings, trials, interrogations, etc., where particular attention can be paid not only to specialised vocabulary, but also to specific conversation strategies and speech acts that are at play based on the situation, as well as to register variation according to 
the participants' roles - e.g., judge/lawyer vs. peer to peer (colleagues) vs. expert/non-expert (lawyer and client).

Clip 2 is from episode 2, lasts approximately 3 minutes (00:03:03) and shows a pre-trial hearing for a civil suit involving the abuse of a prostitute, and therefore it is set in the Circuit courtroom in the Civil Court building. The participants are Judge Abernathy, Mr. Ericcson (State's Attorney), Mr. McKeon (Ericcson’s client), Will Gardner (lawyer), Alicia Florrick (lawyer and second chair in this case), Christy Barbosa (Gardner and Florrick's client), and Kalinda (Gardner's investigator). This clip was selected because it is interestingly divided into two parts. In the first part, Will Gardner and his investigator Kalinda are entering the Civil Court building while talking about the pre-trial hearing, when Alicia Florrick joins them and then they all meet their client, Christy Barbosa, in the lobby. This first sequence, by taking place just outside the courtroom, is particularly interesting because Will Gardner has the chance to explain to his investigator, Kalinda, first, and his client, Christy, second, who are both non-experts, what a pre-trial hearing is. In doing so, he mingles specialised terms and phrases (highlighted in italics in the following transcription in Table 2) with extremely colloquial expressions (in bold), in order to be as clear as possible. These explanatory sequences aim also at popularization, by explaining legal matters to viewers.

\begin{tabular}{|l|l|l|}
\hline 1 & WILL to Kalinda & $\begin{array}{l}\text { This is a pre-trial hearing, so don't worry about the driver yet. We just } \\
\text { need to win a few motions. }\end{array}$ \\
\hline 2 & $\begin{array}{l}\text { ALICIA (arriving } \\
\text { late) }\end{array}$ & Sorry! \\
\hline 3 & WILL & $\begin{array}{l}\text { Don't worry about it. } \\
\text { to Kalinda }\end{array}$ \\
\hline & Entering the building, security check in the lobby \\
\hline 4 & KALINDA & $\begin{array}{l}\text { Still no luck finding the other stripper. All we have is a first name, } \\
\text { "Maura", and a general description. }\end{array}$ \\
\hline 5 & WILL & $\begin{array}{l}\text { We need to box McKeon in. There's only one of two ways his semen } \\
\text { ends up in that rape kit: consensual sex or rape. We get him to swear } \\
\text { there was no consensual sex. }\end{array}$ \\
\hline 6 & KALINDA & Why would he do that? \\
\hline 7 & ALICIA & 'Cause he has a wife. \\
\hline & CHRISTY is in the lobby, waiting for them \\
\hline
\end{tabular}




\begin{tabular}{|c|c|c|}
\hline 8 & WILL to Christy & There you are. How you doing? You nervous? \\
\hline 9 & CHRISTY & No, but maybe I should be? \\
\hline 10 & to Kalinda & $\begin{array}{l}\text { This is just a pre-trial hearing. State's attorney's trying to squash our } \\
\text { subpoena, so today we just get the ground rules straight, in case this } \\
\text { thing goes to trial. } \\
\text { Kalinda, I need you to get upstairs, get in the State's attorney's office and } \\
\text { wait for the subpoena. }\end{array}$ \\
\hline 11 & ALICIA to Will & I'll do that. \\
\hline 12 & WILL & What? You don't have to. \\
\hline 13 & ALICIA & I know. I'll be back. \\
\hline 14 & WILL & You all right? \\
\hline 15 & ALICIA (leaves) & Yeah, sure, I'm fine. \\
\hline 16 & $\begin{array}{l}\text { WILL (reading a } \\
\text { sign on the wall) } \\
\text { to Christy }\end{array}$ & $\begin{array}{l}\text { Oh, my God, this is too good! } \\
\text { We got Judge Abernathy! }\end{array}$ \\
\hline 17 & CHRISTY & Judge/ \\
\hline 18 & WILL (smiling) & $\begin{array}{l}\text { He's our newest judge. He's so liberal, he makes Michael Moore look } \\
\text { like Rush Limbaugh. Justice may be blind, but judges sure aren't. God, } \\
\text { Ericcson must be pulling his hair out! }\end{array}$ \\
\hline
\end{tabular}

Table 2. Transcription of the first part of Clip 2.

Such an informal register is also used to reassure his client, which is something that is achieved both on the verbal and non-verbal levels. In the first case, with the use of a humorous joke in order to describe Judge Abernathy in turn 18, by comparing the famous American director Michael Moore to the American radio talk show host and conservative political commentator Rush Limbaugh. In the latter case, with gestures (occurring along with the underlined words in the transcription above), as in the explanatory sequence in turn 10 , when Mr. Gardner tries to illustrate to his client the strategy he is going to adopt in the pretrial hearing, by using the gesture labelled as "Pd", i.e., palm down, with a modal function, in order to appear self-confident to his client (Fig. 2). 


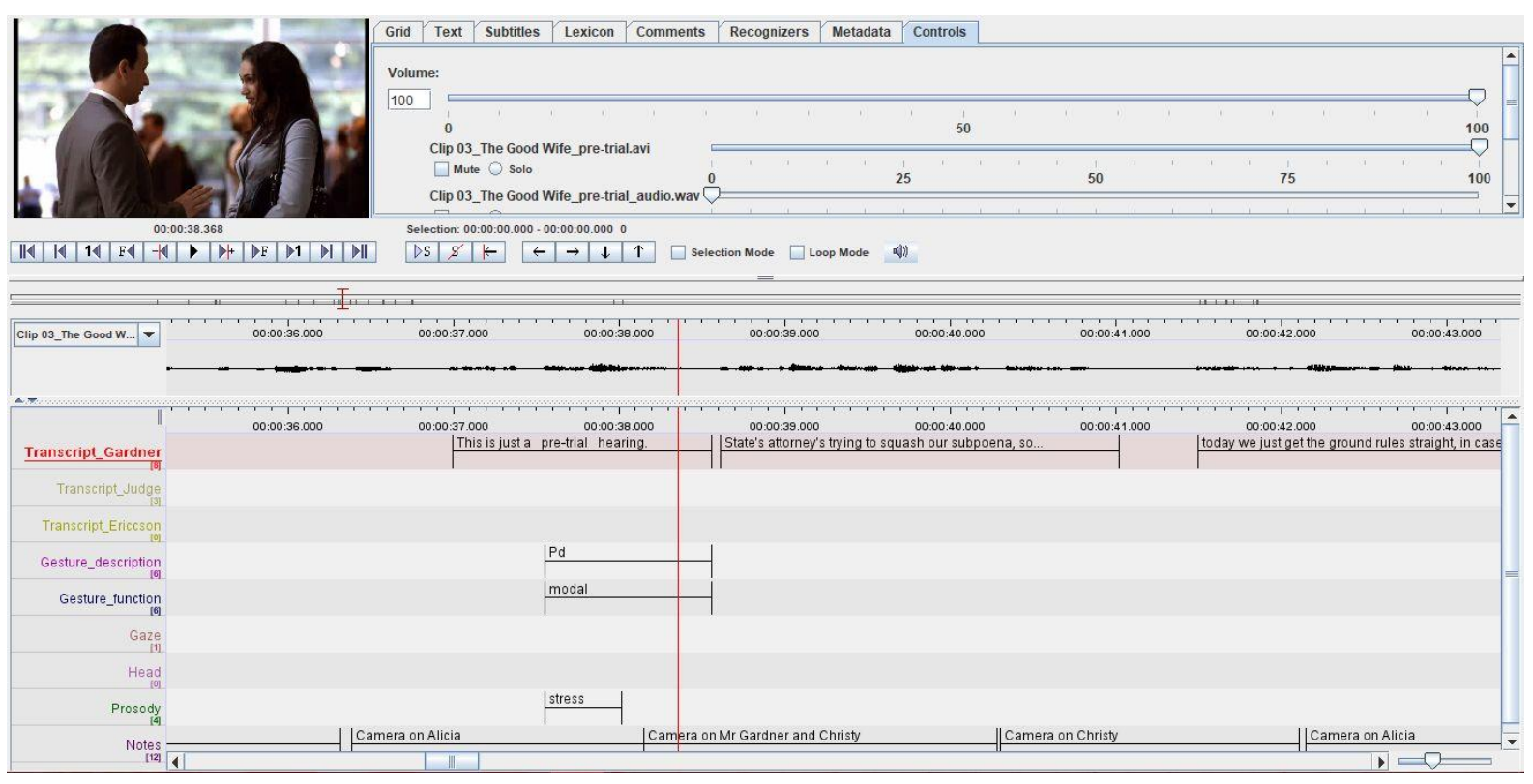

Fig.2 - Gesture performing a modal function (Clip 2)

In the second part of the clip, they all enter (except Alicia) the court room, Mr. Ericcson is seated next to his client, and the pre-trial hearing starts. The first thing to notice from the transcription below (Table 3) is an abrupt shift in register, which is very formal, as required by the situational context. Since the pre-trial hearing is a session with the judge where the lawyers of both sides have to negotiate the case before going to trial, the dialogue is characterised by a series of questions (in bold) and responses and by specialised vocabulary (in italics) with legal terms (mostly also diatopically marked, as in the case of docket, the US legal term for a list of cases), collocations and formulaic expressions (e.g. Your Honor, All rise for Judge A., Court adjourned). Gestures are employed by all three speakers and their presence is indicated by the underlined words with which they co-occur.

\begin{tabular}{|l|l|l|}
\hline 19 & VOICE (man) & All rise for Judge Abernathy. \\
\hline 20 & $\begin{array}{l}\text { JUDGE } \\
\text { ABERNATHY }\end{array}$ & $\begin{array}{l}\text { Oh, please, don't stand. Everybody sit back down, please. We've got the } \\
\text { big room here, don't we? }\end{array}$ \\
\hline 21 & ERICCSON & $\begin{array}{l}\text { Your Honor, given the stature of my client, Mr. McKeon, and given the } \\
\text { fact that this pre-trial hearing has already garnered the attention of our } \\
\text { friends in the press, we would ask the court to seal the pre-trial filings } \\
\text { and avoid a show trial. }\end{array}$ \\
\hline 22 & JUDGE & Oh, Mr. Ericcson, I don't think we need to do all that, do we? First \\
\hline
\end{tabular}




\begin{tabular}{|c|c|c|}
\hline & $\begin{array}{l}\text { ABERNATHY } \\
\text { to Will }\end{array}$ & $\begin{array}{l}\text { amendment issues and all? I deny the petition ... with regret. } \\
\text { Mr. Gardner? }\end{array}$ \\
\hline 23 & WILL & $\begin{array}{l}\text { Yes, Your Honor. We have a lot of testimony focusing on whether there } \\
\text { was a consensual act between Mr. McKeon and... my client, but if Mr. } \\
\text { McKeon is willing to stipulate there was, indeed, a consensual sexual act, } \\
\text { we would forego this testimony. }\end{array}$ \\
\hline 24 & $\begin{array}{l}\text { JUDGE } \\
\text { ABERNATHY } \\
\text { to Ericcson }\end{array}$ & $\begin{array}{l}\text { That's a good point. } \\
\text { Mr. Ericcson, how do you respond? }\end{array}$ \\
\hline 25 & McKeon whispers & omething to Ericcson \\
\hline 26 & $\begin{array}{l}\text { ERICCSON to } \\
\text { Judge Abernathy }\end{array}$ & $\begin{array}{l}\text { We will stipulate there was no sex of any kind, forced or consensual, Your } \\
\text { Honor. }\end{array}$ \\
\hline 27 & $\begin{array}{l}\text { WILL to Judge } \\
\text { Abernathy }\end{array}$ & $\begin{array}{l}\text { The plaintiff also requests an expedited trial date, Your Honor, a DNA } \\
\text { sample from Mr McKeon, DNA results from the rape kit, and the } \\
\text { investigative reports from the state's attorney's office. They have been... } \\
\text { reluctant to furnish them. }\end{array}$ \\
\hline 28 & $\begin{array}{l}\text { JUDGE } \\
\text { ABERNATHY } \\
\text { to Ericcson }\end{array}$ & $\begin{array}{l}\text { Thank you, counselor. I will grant all four motions. } \\
\text { Mr, uh... Ericcson? }\end{array}$ \\
\hline 29 & $\begin{array}{l}\text { ERICCSON } \\
\text { makes a gesture }\end{array}$ & \\
\hline 30 & $\begin{array}{l}\text { JUDGE } \\
\text { ABERNATHY }\end{array}$ & $\begin{array}{l}\text { Ah. I interpret from Mr. Ericcson's, uh, gesture that he acquiesces. Well, } \\
\text { I'll see you all back here... Let's see. My docket is clear. Five days? } \\
\text { How's that for expedited? Uh, as a side note, I would like to ask for a } \\
\text { moment of silence for the recent mass killings in Darfur. } \\
\text { Okay, thank you. Court adjourned. }\end{array}$ \\
\hline
\end{tabular}

Table 3. Transcription of the second part of Clip 2.

However, as can be noticed in turn 29, there is one case in which Mr. Ericcson responds to the judge's invitation to intervene in the negotiation process solely by using a gesture - i.e., thumb, forefinger and middle finger moving back and forth (Fig. 3). This gesture has a performative function, since it substitutes his verbal answer, which is ironically repeated and interpreted by the judge himself in the next turn. Mr. Ericcson's attitude is extremely impolite and does not respect the hierarchy of the judicial system, as the judge indeed has more authority than a State's attorney; however, on the one hand, he takes advantage of Judge Abernathy's liberal character, and on the other, such an attitude reflects his uptight and eccentric nature, as his clothes (an elegant suit with lilac matching accessories) also suggest (see still image in Fig. 3). 

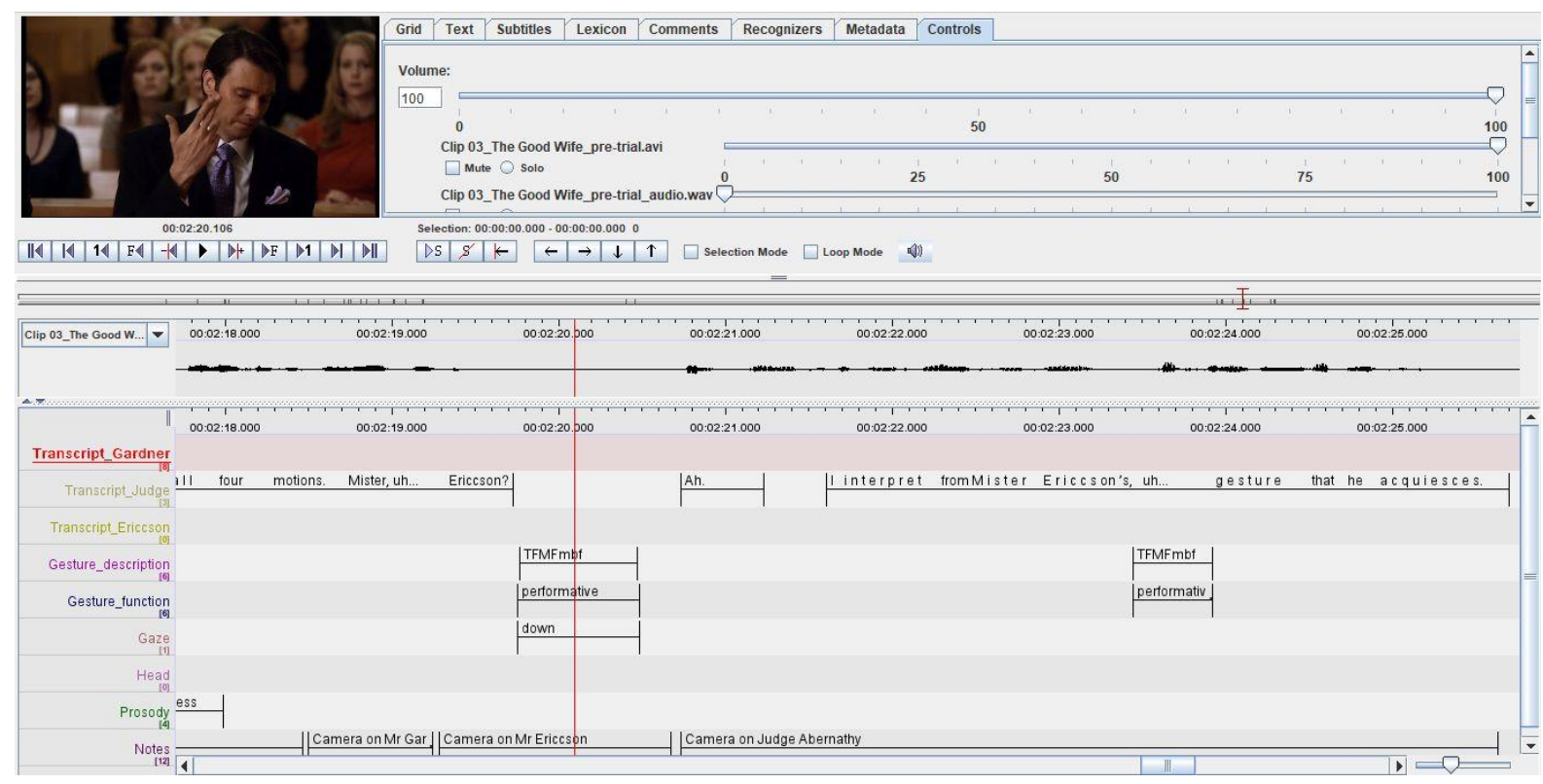

Fig. 3 - Gesture with a performative function not accompanied by speech (Clip 2)

How could this clip be used in class? Firstly, it is important to set the background by briefly introducing the TV series in question, which may not be familiar to all students, even though it is a very popular show, also pointing out that it is about the American legal system, and the scene shown in the clip itself. Secondly, students should watch the whole clip first, and then focus on the first part, that is, the one taking place outside the courtroom. A watching/listening comprehension exercise could be carried out, with a fill in the blanks exercise on specialised vocabulary based on the corresponding transcription. The students could watch the first part of the clip again with English subtitles in order to check their answers. Finally, they could watch it again focusing on the participants' roles and trying to make assumptions by analysing both verbal and non-verbal cues. Such an activity should be able to highlight the use of informal register and the expert/non-expert relationship. At this point, attention should be paid to the second part of the clip, set in the courtroom. A similar activity such as the text completion exercise should be carried out, but this time leaving out not only specialised terms, but also parts of collocations (e.g., the verb forego in 'forego this 
testimony' in turn 23) and formulaic expressions (e.g., all rise for in 'All rise for Judge Abernathy' in turn 19), which are in effect recurring and characterising features of courtroom discourse. A further activity could be to watch this part of the clip and note down the gestures used by the interlocutors, and when and why they are used. A discussion with the whole class should follow, and possibly the teacher could add the information retrieved by students using the ELAN file, so that, at the end, they all could actually see how verbal and non-verbal cues interact simultaneously to make meaning in that context. Finally, a True/False comprehension exercise could be done on the whole clip, in order to ascertain if the multimodal analysis has contributed to enhancing understanding. Indeed, as Sherman (2003: 6) points out, the clip could also be used as 'input/stimulus for some other activity'. Such activities could be on the grammar level (i.e., exercises on the interrogative form, using both direct and indirect questions), on the lexical level (i.e., teaching collocations with 'trial'), and regarding the main topics of the course (i.e., explaining the different types of trials in the U.S.).

\subsection{Tourism}

The 25 clips pertaining to the domain of tourism were extracted from three films, namely Under the Tuscan Sun (2003, A. Wells), Letters to Juliet (2010, G. Winick) and To Rome with Love (2012, W. Allen), all mainly set in various regions of Italy. They basically show some selected scenes portraying different and varied contexts - e.g. restaurant, hotel, sightseeing, etc. - where distinctive semantic fields can be singled out through the use of certain key terms and collocations relevant in tourism discourse. These clips are also characterised by a great number of cultural references and, especially, cultural and linguistic stereotypes, through which the interplay between visual and aural cues becomes crucial to build up the destination image. Relating to this, in recent studies of marketing (among many, Morgan and Pritchard 1998) the role of films has been recognized as pivotal for the increase in the number of tourists in locations where the films were set, thus giving birth to the so- 
called "movie-induced tourism" (Riley, Baker and Van Doren 1998) or "film tourism" (Hudson and Ritchie 2006), defined as "tourist visits to a destination or attraction as a result of the destination's being featured on television, video, or the cinema screen" (2006: 387). In fact, setting a film in a certain location has become, according to Morgan and Pritchard (1998), the ultimate in tourism product placement. These are fundamental concepts for students of the tourism class.

The clip that will be analysed in this section is from Letters to Juliet, a romantic comedy based on the novel of the same name by Ceil and Lise Friedman and it tells the story of Sophie, an American journalist, who goes to Verona with her fiancé, Victor, a chef who is going to open a new restaurant in New York, as a sort of pre-honeymoon. However, the supposedly romantic trip becomes a solitary holiday, as Victor is always busy meeting his suppliers. But while visiting Juliet's home, Sophie meets the "Secretaries of Juliet", a group of volunteers who every night collect the letters left by tourists under Juliet's famous balcony and answer back giving advice. Sophie decides to help them and suddenly finds, hidden behind a stone, the unanswered letter of an English teenager who visited Verona fifty years before and decides to go and look for her.

Clip 3, approximately 3 minutes long, shows a sequence at the beginning of the film, when Sophie and Victor have just arrived in Verona and we see her sightseeing around the city, but then Victor drags her on a private tour to the surrounding countryside to meet his suppliers, i.e., Italian farmers such as a grape grower, a wine maker, and a cheese maker. This clip will be analysed in a different way with respect to the previous two clips, by taking into account first the verbal elements, then the visual cues, and finally integrating the visual with the aural cues.

If we analyse the verbal elements first, we can notice the use of code-switching from English to Italian, when Victor talks to the Italian farmers, and of code-mixing, as Victor uses Italian words while speaking in English even to his fiancée (e.g., Ciao, I love this place!; I just got 
off the phone with Signor Morini, and he's arranged a private tour for us with each and every one of my suppliers), which contributes to creating a sort of 'exotic' atmosphere, especially for the American audience.

The visual cues in this clip are very interesting. At the very beginning, several images of the landmarks of the city of Verona (Fig. 4) are shown as in a documentary or promotional video: a long shot of the river Adige, the famous Roman arch bridge Ponte Pietra (roughly 'Stone Bridge'), which is the oldest bridge in Verona, the main square, namely Piazza delle Erbe, and, last but not least, the Arena. Then, in the second part of the clip, when we follow Sophie and Victor in the surrounding countryside, we encounter some of the most important (and culturally relevant) Italian products (Fig. 5), ranging from a red convertible FIAT 500 to wine, cheese and olive oil. Such elements all contribute to the stereotypical image of wellbeing, happiness, style and the love for food and wine of Italy as 'il Bel Paese'.

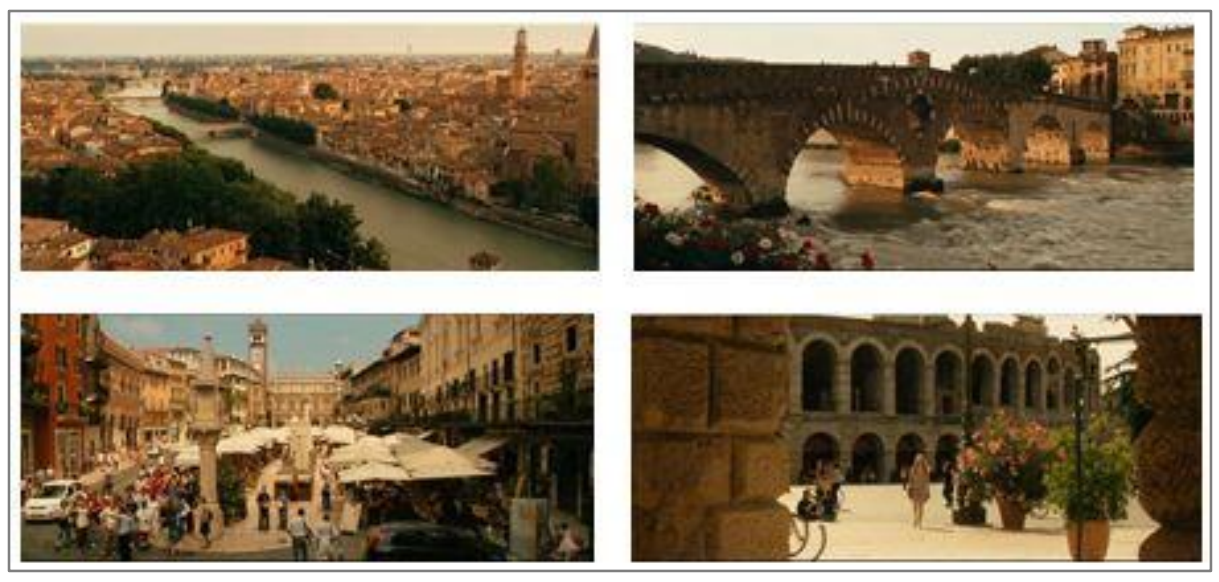

Fig. 4 - Visual cues in Clip 3: The landmarks of Verona 


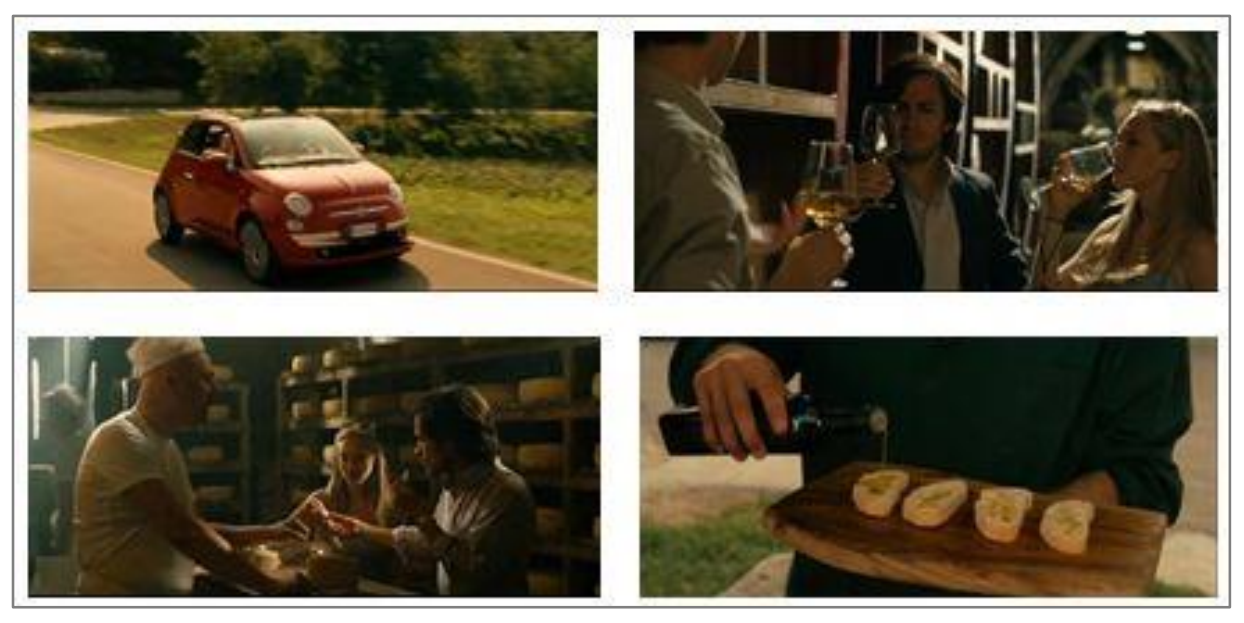

Fig. 5 - Visual cues in Clip 3: Products of Italy

Finally, by analysing the aural cues in this clip and integrating them with the images, the attempt to create a stereotypical image of Italy as a holiday destination for Americans in particular is quite striking. For instance, in the opening scene of the clip, the view of Verona (cf. first image in Fig. 4) is accompanied by some light background music and especially by bells tolling - a recurring element in all three films analysed in the multimodal corpus which are a specific cultural reference to Italian traditions and religion. Then, in the following scene, when we see Sophie as a tourist wandering in the streets of the city, we can hear a couple of male voices off screen courting her in Italian, but with an unrealistic Roman accent (e.g., Ehi, bella Americana, guarda qui! So' Francesco!), or a car honking because she is a pretty woman (Fig. 6). This is simply a tribute to the stereotypical image of Italian men as lovers, but scenes like these hardly ever happen in reality, and even less often in the north of Italy. 


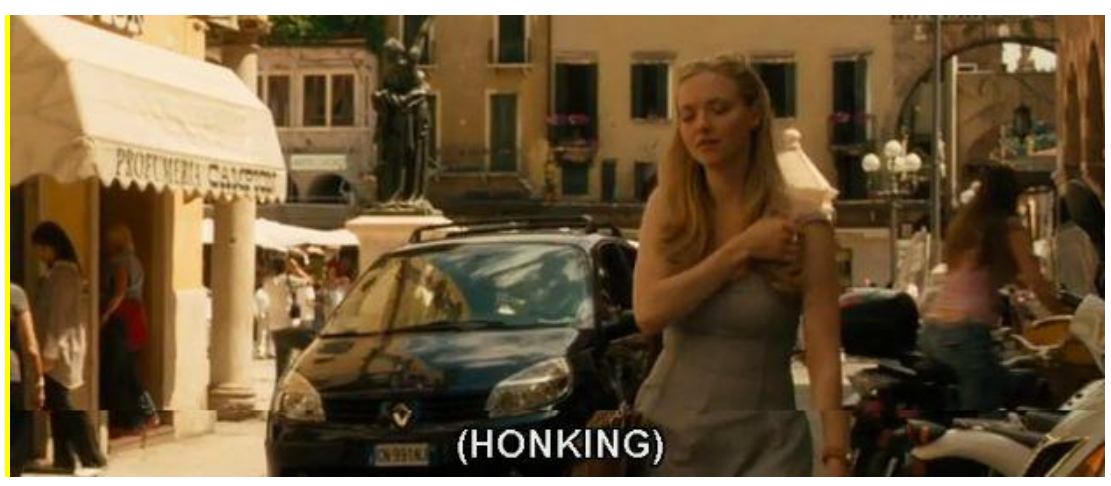

Fig. 6 - Visual and aural cues in Clip 3

One last example is when we see Sophie and Victor in their red convertible FIAT 500 driving in the countryside near Verona (cf. first image in Fig. 5) with a Neapolitan tarantella played with a mandolin as background music.

The present clip was actually used in an English for Tourism class, with around 45 Italian university students attending the second year of the Tourism Science programme. After briefly introducing both the film and the clip, they watched the whole clip once. Then they were given a handout with the partial transcript, where some key terms and collocations relevant in tourism discourse (e.g., words pertaining to the semantic field of 'wine' such as grape and vineyard, and the verb arranged followed by its collocates 'a private tour') and some verb forms were missing (e.g., stop checking, start writing, tried to talk, as part of the grammar revision regarding verbs followed by the infinitive or the gerund). They were instructed to watch the clip again in order to fill in the blanks with the missing items. After the correction, they were asked to watch the clip twice: first, noting down the audio elements they could hear besides the main characters' dialogues, i.e., voices, noises, soundtrack music, and everything related to the so-called "soundscape" (van Leeuwen 1999, cf. Francesconi 2014, who analyses it in tourism texts); second, noting down the visual elements they found relevant in the clip, e.g., clothes, objects, food, vehicles, landscapes, gestures, etc. The final question was if they found the whole ensemble corresponding to an authentic portrayal of 
Italy. This lead to a discussion on Italian stereotypes and the construction of the holiday destination, based on a certain tourist type, i.e., targeted to Americans, in this case.

\section{Conclusions}

The main aim of the present work was twofold: first, to present the ESP multimodal corpus of film and TV series clips, and second, to give an overview of how these clips can be utilised to teach English in the ESP class.

The analysis carried out so far has shown the richness of audiovisual resources also in specialised domains. Indeed, ESP students could benefit from the use of clips in class for several reasons: 1) they are exposed to English by native speakers, and to its different varieties; 2) they get to "see" the language used in specialised contexts and in different genres; 3) being multimodal in nature, clips offer students the chance of being aware of how different modes can actually altogether contribute to the meaning-making process; 4) students could see to what extent non-verbal elements such as gestures or the use of prosodic stress can be of help in the construction of meaning; and finally, 5) clips offer a more hands-on approach to the language, with a wide range of activities targeted to developing different skills.

A further step in this work would be to enlarging the multimodal corpus by including clips cut from films and TV series representing other domains such as Technology, and to carry out a similar analysis using clips in the other two domains that were omitted from the present study, i.e., Business \& Economics and Health \& Medicine.

\section{References}

Ackerley, K., \& Coccetta, F. (2007). Enriching language learning through a multimedia corpus. ReCALL, 19(3), 351-370. 
Atkinson, M. (1984). Our Master's Voices. The Language and Body Language of Politics. London: Methuen.

Bateman, J.A. (2013). “Multimodality and film”. In Chapelle, C.A. (Ed.) The Encyclopedia of Applied Linguistics (pp. 4030-4033). Oxford: Blackwell.

Beard, A. (2000) The Language of Politics. London: Routledge.

Bednarek, M. (2010). The Language of Fictional Television: Drama and Identity. London/New York: Continuum.

Bonsignori, V. (2013). English Tags. A Close-up on Film Language, Dubbing and Conversation. Newcastle-upon-Tyne: Cambridge Scholars Publishing.

Bonsignori, V. (2016). Analysing political discourse in film language: A multimodal approach. In V. Bonsignori, \& B. Crawford Camiciottoli (Eds.), Multimodality across Communicative Settings, Discourse Domains and Genres (pp. 189-211). NewcastleUpon-Tyne: Cambridge Scholars.

Bruti, S. (2015). Teaching learners how to use pragmatic routines through audiovisual material. In B. Crawford Camiciottoli, \& I. Fortanet-Gómez (Eds.), Multimodal Analysis in Academic Settings. From Research to Teaching (pp. 213-236). London: Routledge.

Chaume, F. (2004). Cine y Traducción. Catedra: Signo e Imagen.

Csomay, E., \& Petrović, M. (2012). “Yes, your honor!”: A corpus-based study of technical vocabulary in discipline-related movies and TV shows. System, 40, 305-315. doi:10.1016/j.system.2012.05.004

Dikilitas, K., \& Duvenci, A. (2009). Using popular movies in teaching oral skill. Procedia Social and Behavioral Sciences, 1(1), 168-172. doi:10.1016/j.sbspro.2009.01.031

Forchini, P. (2012). Movie Language Revisited. Evidence from Multidimensional Analysis and Corpora. Bern: Peter Lang. 
Forchini, P. (2017). A multi-dimensional analysis of legal American English: Real-life and cinematic representations compared. International Journal of Language Studies, 11(3), 133-150.

Francesconi, S. (2014). Reading Tourism Texts: A Multimodal Analysis. Bristol: Channel View Publications.

Gregory, M., \& Carroll, S. (1978). Language and Situation: Language Varieties and Their Social Contexts. London: Routledge \& Kegan Paul.

Harmer, J. (2007). The Practice of English Language Teaching. 4th ed. Harlow, UK: Pearson Longman.

Hudson, S., \& Ritchie, J.R.B. (2006). Promoting destinations via film tourism: An empirical identification of supporting marketing initiatives. Journal of Travel Research, 44, 387396.

Jewitt, C. (Ed.) (2014). The Routledge Handbook of Multimodal Analysis. London: Routledge.

Kaiser, M. (2011). New approaches to exploiting film in the foreign language classroom. L2 Journal, 3(2), 232-249. Accessed July 30, 2017. http://escholarship.org/uc/item/6568p4f4.

Kalantzsis, M. \& Cope, B. (2013) Multiliteracies in education. In C.A. Chapelle (Ed.), The Encyclopedia of Applied Linguistics. Oxford: Blackwell, 3963-3969.

Kendon, A. (2004). Gesture: Visible Action as Utterance. Cambridge: CUP.

Knight, D. (2011). The future of multimodal corpora. Revista Brasileira de Linguistica Aplicada, 11(2), 391-415.

Kozloff, S. (2000). Overhearing Film Dialogue. Berkeley: University of California Press. Kress, G. (2003). Literacy in the New Media Age. London: Routledge.

Kress, G., \& van Leeuwen, T. (1996). Reading Images. The Grammar of Visual Design. London/New York: Routledge. 
Lemke, J.L. (1998). Multiplying meaning: Visual and verbal semiotics in scientific text. In J. R. Martin, \& R. Veel (Eds.), Reading Science: Critical and Functional Perspectives on Discourses of Science (pp. 87-113). London: Routledge.

Lin, P.M.S. (2014). Investigating the validity of internet television as a resource for acquiring L2 formulaic sequences. System, 42, 164-176.

Morgan, N., \& Pritchard, A. (1998). Tourism Promotion and Power: Creating Images, Creating Identities. Chichester, UK: John Wiley \& Sons.

Nagy, B. (2010). Medical English: Textbooks and medical dramas. SKASE Journal of Theoretical Linguistics, 7(2), 67-71.

New London Group (1996). A pedagogy of multiliteracies: Designing social futures. Harvard Educational Review, 66(1), 60-92.

Norris, S. (2004). Analyzing Multimodal Interaction: A Methodological Framework. London: Routledge.

O’Halloran, K.L. (2011). Multimodal discourse analysis. In K. Hyland \& B. Paltridge (Eds.), Companion to Discourse Analysis (pp. 120-137). London: Continuum.

O’Halloran, K.L., Tan, S., \& Smith, B.A. (2016). Multimodal approaches to English for academic purposes. In Hyland, K., \& Shaw, P. (Eds.), The Routledge Handbook of English for Academic Purposes (pp. 256-269). London: Routledge.

Partington, A., \& Taylor, C. (2010). Persuasion in Politics. A Textbook. Milano: LED.

Poggi, I., D’Errico, F., Vincze, L., \& Vinciarelli, A. (Eds.) (2013). Multimodal Communication in Political Speech: Shaping Minds and Social Actions. Berlin: Springer.

Quaglio, P. (2009). Television Dialogue. The Sit-com Friends vs. Natural Conversation. Amsterdam/Philadelphia: John Benjamins Publishing Company.

Querol-Julián, M. (2010). Multimodality in discussion sessions: Corpus compilation and pedagogical use. Language Value, 2(1), 1-26. 
Querol-Julián, M. (2011). Evaluation in Discussion Sessions of Conference Paper Presentation: A Multimodal Approach. Saarbrücken: LAP Lambert Academic Publishing.

Riley, R., Baker, D., \& Van Doren, C.S. (1998). Movie induced tourism. Annals of Tourism Research, 25(4), 919-935.

Rizzo, C.R. (2010). Getting on with corpus compilation: From theory to practice. ESP World, 1(27), 9 .

Scollon, R., \& Levine, P. (Eds.). (2004). Multimodal Discourse Analysis as the Confluence of Discourse and Technology. Washington, DC: Georgetown University Press.

Sherman, J. (2003) Using Authentic Video in the Language Classroom. Cambridge: CUP.

Streeck, J. (2008). Gesture in political communication: A case study of the democratic presidential candidates during the 2004 primary campaign. Research on Language and Social Interaction, 41(2), 154-186.

Van Leeuwen, T. (1999). Speech, Music, Sound. Houndmills and London: MacMillan.

Vyushkina, E. (2016). Legal English through movies: Development of professional communicative competence. Studies in Logic, Grammar and Rhetoric, 45, 253-263. DOI: $10.1515 / \mathrm{slgr}-2016-0027$.

Webb, S., \& Rodgers, H. (2009). The lexical coverage of movies. Applied Linguistics, 30, 407-427, https://doi.org/10.1093/applin/amp010

Weinberg, A., Fukawa-Connelly, T., \& Wiesner, E. (2013). Instructor gestures in proof-based mathematics lectures. In Martinez, M., \& A. Castro Superfine (Eds.), Proceedings of the 35th annual meeting of the North American Chapter of the International Group for the Psychology of Mathematics Education (p. 1119). Chicago: University of Illinois at Chicago.

Wittenburg, P., Brugman, H., Russel, A., Klassmann, A., \& Sloetjes, H. (2006). ELAN: A professional framework for multimodality research. In Proceedings of LREC 2006, 
Fifth International Conference on Language Resources and Evaluation. Accessed July 30, 2017. http://www.lrec-conf.org/proceedings/lrec2006/pdf/153_pdf.pdf.

1 The present study is also part of a research project financed by the Italian Ministry for the University (PRIN 2015 no.2015TJ8ZAS).

${ }^{2}$ http://blcvideoclips.berkeley.edu/

${ }^{3}$ The clips extracted from the TV series Code Black are a new addition to the multimodal corpus and have not been published on the BLC LFLFC website.

${ }^{4}$ ELAN was developed at the Max Planck Institute for Psycholinguistics, The Language Archive, Nijmegen, The Netherlands. It is freely available at http://tla.mpi.nl/tools/tla-tools/elan/. 